\title{
Glyphosate-based herbicide affects biochemical parameters in Rhamdia quelen (Quoy \& Gaimard, 1824 and) Leporinus obtusidens (Valenciennes, 1837)
}

\author{
Vania Lucia Loroํ, Lissandra Glusczakㄹ, Bibiana S. Moraes ${ }^{1}$, Claudio A. M. Leal², \\ Charlene Menezes ${ }^{1}$, Camila R. Murussi ${ }^{1}$, Jossiele Leitemperger ${ }^{1}$, Maria Rosa C. \\ Schetinger ${ }^{2}$ and Vera Maria Morsch ${ }^{2}$
}

\begin{abstract}
Rhamdia quelen (silver catfish) and Leporinus obtusidens (piava) were exposed to a commercial formulation Roundup ${ }^{\circledR}$, a glyphosate-based herbicide at concentrations of 0.2 or $0.4 \mathrm{mg} / \mathrm{L}$ for $96 \mathrm{~h}$. The effects of the herbicide were analyzed on the alanine aminotransferase (ALT) and aspartate aminotransferase (AST) activities and glucose in plasma, glucose and protein in the mucus layer, nucleotide hydrolysis in the brain, and protein carbonyl in the liver. The parameters were chosen, owing to a lack of information concerning integrated analysis, considering oxidative damage parameters, liver damage, and effects on the mucus layer composition and triphosphate diphosphohydrolase (NTPDase) activities. Plasmatic glucose levels were reduced in both species, whereas the transaminase activities (ALT and AST) increased after exposure to the herbicide. Herbicide exposure increased protein and glucose levels in the mucus layer in both species. There was a reduction in both NTPDase and ecto-5'-nucleotidase activity in the brain of piava, and increased enzyme activity in silver catfish at both concentrations tested. The species showed an increase in protein carbonyl in the liver after exposure to both concentrations of the glyphosate. Our results demonstrated that exposure to Roundup ${ }^{\circledR}$ caused liver damage, as evidenced by increased plasma transaminases and liver protein carbonyl in both of the fish species studied. The mucus composition

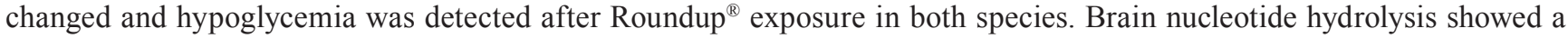
different response for each fish species studied. These parameters indicated some important and potential indicators of glyphosate contamination in aquatic ecosystems.
\end{abstract}

Rhamdia quelen (jundiá) e Leporinus obtusidens (piava) foram expostos a formulação comercial Roundup ${ }^{\circledR}$, um herbicida a base de glifosato nas concentrações de 0,2 e $0,4 \mathrm{mg} / \mathrm{L}$ por $96 \mathrm{~h}$. Os efeitos do herbicida foram analisados na atividade da alanina aminotransferase (ALT), aspartato aminotransferase (AST) e glicose no plasma, glicose e proteína na camada de muco, hidrólise de nucleotídeos no cérebro e a proteína carbonil no fígado. Os parâmetros foram escolhidos devido à falta de informação com relação a análises integradas, considerando parâmetros oxidativo, danos no fígado, efeitos na composição da camada do muco e atividade da trifosfato difosfoidrolase (NTPDase). Níveis de glicose plasmática foram reduzidos em ambas às espécies, enquanto a atividade das transaminases (ALT e AST) aumentou após exposição ao herbicida. A exposição ao herbicida aumentou a proteína e níveis de glicose na camada de muco em ambas as espécies. Houve uma redução em ambas atividades de NTPDase e ecto-5'-nucleotidase no cérebro de piava, e um aumentou a atividade destas enzimas em jundiás em ambas as concentrações testadas. As espécies mostraram um aumento na proteína carbonil no fígado após exposição a ambas as concentrações de glifosato. Nossos resultados demonstraram que a exposição ao Roundup ${ }^{\circledR}$ causou danos no fígado, como evidenciado pelo aumento das transaminases plasmáticas e proteína carbonil no fígado em ambas as espécies de peixes estudadas. A composição do muco alterou e uma hipoglicemia foi detectada após a exposição ao Roundup ${ }^{\circledR} \mathrm{em}$ ambas espécies. A hidrólise de nucleotídeos em cérebro mostrou diferente resposta para cada espécie estudada. Esses parâmetros indicam alguns importantes e indicadores potenciais da contaminação do glifosato no ecossistema aquático.

Keywords: Fish, Mucus, Nucleotidases, Plasma, Protein carbonyl.

\footnotetext{
${ }^{1}$ Laboratório de Bioquímica Adaptativa e Toxicologia Aquática, Departamento de Química, Centro de Ciências Naturais e Exatas, Universidade Federal de Santa Maria, Av. Roraima, 1000, 97105-900 Santa Maria, RS, Brazil. vania.loro@gmail.com(VLL, correspondent author); lissag23@yahoo.com.br (LG); bibianamoraes@gmail.com (BSM); charlenemenezes@yahoo.com.br (CM); camilamurussi@ hotmail.com (CRM); dotism@yahoo.com.br (JL).

${ }^{2}$ Laboratório de Enzimologia, Departamento de Química, Centro de Ciências Naturais e Exatas, Universidade Federal de Santa Maria, Av. Roraima, 1000, 97105-900 Santa Maria, RS, Brazil. camleal@terra.com.br (CAML); mariachitolina@gmail.com (MRCS); veramorsch@gmail.com (VMM).
} 


\section{Introduction}

When present in an aquatic system, chemicals such as herbicides may contaminate fish, plants, and other animals by inducing secondary effects, sometimes owing to indirect contamination (Fonseca et al., 2008). The commercial formulation of glyphosate herbicides contains the isopropylamine (IPA) salt of glyphosate $480 \mathrm{~g} / \mathrm{L}$, water, and polyethoxylated tallow amine surfactant (POEA) (Jiraungkoorskul et al., 2002). According to Piola et al. (2013), ingredients such as POEA are typically classified as "inert"; however, they may be more toxic than the glyphosate itself. Numerous commercial formulations with glyphosate as the active ingredient have become popular worldwide, owing to their effective action, low toxicity to mammals, and reduced cost to the farmer (Corbera et al., 2005). Glyphosate and its principal degradation product, aminomethylphosphonic acid (AMPA), have been found in natural water sources in many countries (Coupe et al., 2012). The glyphosate (commercial formulation Roundup ${ }^{\circledR}$ ) concentration used in rice and soybean cultures in Southern Brazil ranges from 0.36 to $2.16 \mathrm{mg} / \mathrm{L}$ (Rodrigues \& Almeida, 2005). The glyphosate distribution between water, soil, and sediment is influenced by some factors, and it is very difficult to predict the exact environmental behaviors that influence the distribution of the active ingredient or degradation product (AMPA); for example, glyphosate levels measured in April ranged from 0.5 to 4 $\mu \mathrm{g} / \mathrm{L}$ with AMPA ranging from 0.5 to 2.3. In August of the same year, the glyphosate dispersion was between 0.5 and $2.3 \mu \mathrm{g} / \mathrm{L}$ and AMPA ranged from 1.7 to $3.6 \mu \mathrm{g} / \mathrm{L}$ (Aparicio et al., 2013).

There are several studies considering herbicide toxicity in fish, especially concerning metabolic and oxidative parameters in response to glyphosate exposure (Fonseca et al., 2008; Salbego et al., 2010; Glusczak et al., 2011). The mucus layer is important not only because of to its effective role as a protective barrier, but also because it performs a number of functions, including disease resistance, respiration, ionic and osmotic regulation, locomotion, reproduction, communication, and feeding (Subramanian et al., 2008). Some studies have used the mucus layer that covers the exposed surfaces of fish to determine herbicide effects (Glusczak et al., 2011; Menezes et al., 2014). Glusczak et al. (2011) observed an increase in glucose and protein levels in the mucus layer in piavas that had been exposed to different concentrations of glyphosate herbicide, and Menezes et al. (2014) also reported an increase in protein in silver catfish that were exposed to a commercial formulation containing 2,4-D. Glycoproteins represent the major component of the mucus coating of fish skin. Thus, changes in carbohydrate and protein contents of the fish surface could be a mechanism to protect them against external agents and microbial development.

Ectonucleotidases regulate nucleotide-mediated signaling, controlling the rate, amount, and timing of nucleotide degradation as well as their formation (Baldissarelli et al., 2012). The fish presents the triphosphate diphosphohydrolase (NTPDase) activity in brain membranes (Senger et al., 2004; Rico et al., 2011). Thus, extracellular ATP may play an important role in synaptic transmission, acting as a neurotransmitter and/ or a neuromodulator (Cunha et al., 2000; Senger et al., 2005). ATP is the main agonist of $P 2$ receptors, which are subdivided into two main classes: ionotropic P2X receptors and metabotropic $\mathrm{P} 2 \mathrm{Y}$ receptor (Senger et al., 2005). P stands for purinergic, P2 refers to ATP receptors, as opposed to $\mathrm{P} 1$ adenosine receptors. $\mathrm{P} 2 \mathrm{X}$ receptors are ATP activated channels that allow the passage of ions across cell membranes. P2Y receptors are ATP activated $\mathrm{G}$ protein-coupled receptors (GPCRs) that initiate an intracellular chain of reactions. After their release, the neurotransmitter ATP may be converted into adenosine by the family of ectonucleotidases called NTPDase. On the other hand, NTPDase hydrolyzes ATP and AMP, and 5'nucleotidase hydrolyzes AMP to adenosine (Zimmermann, 2001; Senger et al., 2005). In vertebrates, the activity of these enzymes is widely distributed (Senger et al., 2005).

In addition, reactive oxygen species (ROS) play an important role in the toxicity caused by herbicides and other environmental chemical contaminants (Üner et al., 2005). Herbicides are able to stimulate the production of ROS through diverse different mechanisms (van der Oost et al., 2003). Oxidative stress occurs when there is a disruption in the balance between the production and the removal of ROS and other free radicals (Santos et al., 2004; Ortiz-Ordoñez et al., 2011). The highest susceptible targets of oxidative stress are polyunsaturated fatty acids and proteins of the cell membrane (Sevgiler et al., 2007). In mammals, it is known that damage to proteins and amino acids could be attributed to increased protein carbonyl levels (Parvez \& Raisuddin, 2005). Protein carbonyl has been used in several studies with fish to evaluate the effects of pollutants on protein metabolism (Toni et al., 2013).

Rhamdia quelen (Quoy \& Gaimard, 1824) (silver catfish) and Leporinus obtusidens (Valenciennes, 1837) (piava) were chosen because they are native freshwater species of economic importance in Southern Brazil. In addition, they are sensitive to the potential effects of chemicals. Thus, the aim of this study was to investigate the effects of a glyphosate-based herbicide on toxicological parameters such as plasmatic metabolic parameters (ALT, AST and glucose), protein and glucose in the mucus layer, NTPDase and ecto- 5'-nucleotidase activities in the brain, and protein carbonyl levels in liver in silver catfish and piava in the Southern region of Brazil.

\section{Material and Methods}

Silver catfish and piava (female and males) were randomly selected $(11.0 \pm 1.0 \mathrm{~g}$ and $7.0 \pm 1.0 \mathrm{~cm}$, mean of the measurements for both species) and obtained 
from the fish farm of the Universidade Federal de Santa Maria (UFSM, Rio Grande do Sul, Brazil). The fish were acclimated to the laboratory conditions for 10 days and kept in continuously aerated tanks $(250 \mathrm{~L})$ with a static system and with a natural photoperiod $(12 \mathrm{~h}$ light $/ 12 \mathrm{~h}$ dark). Throughout the experimental period, the water quality was as follows: temperature $25 \pm 0.5^{\circ} \mathrm{C}, \mathrm{pH} 7.5$ \pm 0.05 units, and dissolved oxygen $7.2 \pm 0.2 \mathrm{mg} / \mathrm{L}$. Fish were fed once a day with commercial fish pellets $(42 \%$ crude protein, Supra, Brazil). Feces and pellet residues were removed daily through suction.

Previous experiments carried out in our laboratory were unable to obtain a lethal concentration $\left(\mathrm{LC}_{50}\right)$ of glyphosate at $96 \mathrm{~h}$, because all the fish survived, even at the highest concentration tested $(100 \mathrm{mg} / \mathrm{L})$ and showed normal swimming and feeding behaviors. Thus, the experimental glyphosate concentrations were chosen according to Rodrigues \& Almeida (2005), considering the minimum amount of herbicide used in rice-field systems. Furthermore, theses concentrations were used in previous studies in the laboratory with silver catfish, which demonstrated that the glyphosate concentrations used in agriculture may cause changes in the metabolic and enzymatic parameters of fish (Glusczak et al., 2007).

After the acclimation period, groups of six fish (duplicate) were placed in $45 \mathrm{~L}$ tanks, which were continuously aerated and were exposed to the commercial formulation Roundup ${ }^{\circledR}$, a glyphosate-based herbicide (480 $\mathrm{g} / \mathrm{L}$ acid equivalent, $692 \mathrm{~g} / \mathrm{L}$ inert ingredients, Monsanto Company, St Louis MO, USA) for 96h, at concentrations of 0.0 (control), 0.2 or $0.4 \mathrm{mg} / \mathrm{L}$ The herbicide was only added to the water at the beginning of the experiment. The water parameters (temperature, $\mathrm{pH}$, dissolved oxygen) were monitored and the values did not change significantly in comparison with the acclimation period. The fish did not receive food during the experimental period.

At the end of the exposure period (96 h), the mucus was carefully scraped from the dorsal body surface (total area $15 \mathrm{~cm}^{2}$ ) using a swab. After scraping, the swab was immersed in $2 \mathrm{~mL}$ of distilled water, and the sample was used to determine carbohydrate (DuBois et al., 1956) and protein levels (Lowry et al., 1951). All fish were sampled and blood was collected from the caudal vein with heparinized syringe. One blood aliquot was centrifuged at $1500 \mathrm{x} g$ for $10 \mathrm{~min}$ and the plasma was separated. The plasma glucose was measured by the glucose oxidase method with a Bioclin test kit, and aspartate aminotransferase (AST) and alanine transaminase (ALT) activities were also measured using a Bioclin test kit. The fish were anesthetized with $0.1 \mathrm{~g} / \mathrm{L}$ of benzocaine hydrochloride (60 at 180 seconds), according to Antunes et al. (2008). After, the fish were euthanized by spinal sectioning, and the brain and liver were removed, washed in $150 \mathrm{mM}$ saline solution, packed in Teflon tubes and kept at $-80^{\circ} \mathrm{C}$ for posterior analyses. All protocols used in this study were approved by the Committee on Ethics and
Animal Welfare of the Federal University of Santa Maria protocol number: 056-2013.

NTPDase and 5'- nucleotidase activities. Brain samples were homogenized in 10 volumes $(\mathrm{w} / \mathrm{v})$ of $5 \mathrm{mM}$ Hepes buffer ( $\mathrm{pH}$ 7.5) using a glass homogenizer. The samples were centrifuged at $3500 \mathrm{x} \mathrm{g}$ at $5^{\circ} \mathrm{C}$ for $5 \mathrm{~min}$ in order to obtain cell-free supernatants (S1). The supernatant (S1) was added to the reaction medium and used for enzymatic assays.

The NTPDase enzymatic assay of the brain was performed using the method described by Schetinger et al. (2001). The reaction was initiated by the addition of ATP or ADP, as the substrate, to obtain a final concentration of $10 \mathrm{mM}$. The activity of 5'-nucleotidase was determined, as described by Barnes et al. (1993). The reaction was initiated by the addition of AMP, as the substrate, to a final concentration of $10 \mathrm{mM}$. The released inorganic phosphate (Pi) was assayed, as described by (Chan et al., 1986), using malachite green as the colorimetric reagent and $\mathrm{KH}_{2} \mathrm{PO}_{4}$ as a standard. All samples were analyzed in triplicate. Enzyme activities were reported as nmol Pi released/min/ $\mathrm{mg}$ of protein.

Carbonyl protein determination. Carbonyl protein determination was determined in the liver by the method of Yan et al. (1995). Total carbonylation was calculated using a molar extinction coefficient of $22,000 \mathrm{M} / \mathrm{cm}$ and was expressed as nmol carbonyl/mg protein. This method was also been described by Toni et al. (2013).

Protein determination. The protein content, nucleotide hydrolysis, and protein carbonyl levels were measured by the method of Lowry et al. (1951), and bovine serum albumin was used as the standard.

Statistical procedures. A normal distribution and homogeneity of the data were confirmed by KolmogorovSmirnov and Bartlett's test, respectively. The data were analyzed by one-way analysis of variance (ANOVA), followed by Duncan's multiple range tests. The data were expressed as mean \pm standard deviation (SD), and the mean differences were considered significant at $\mathrm{P} \leq 0.05$.

\section{Results}

The effects of glyphosate on the activity of glucose, ALT, and AST in the plasma were observed in silver catfish and piava after exposure to two different glyphosate concentrations $(0.2$ and $0.4 \mathrm{mg} / \mathrm{L})$ for $96 \mathrm{~h}$. The plasmatic glucose levels became reduced in the silver catfish after exposure to glyphosate at both 0.2 and $0.4 \mathrm{mg} / \mathrm{L}$ when compared to the control group (Table 1). In piava, the glucose levels only decreased at $0.4 \mathrm{mg} / \mathrm{L}$, with respect to the control (Table 1). On the other hand, the ALT and AST activities increased in the both concentrations in silver catfish and piava (Table 1). 
Table 1. Plasma metabolic parameters in Rhamdia quelen and Leporinus obtusidens after glyphosate exposure (96 h). ALT and AST were expressed by UI/dL and glucose was expressed by $\mathrm{mg} / \mathrm{dL}$. Data represent the mean $\pm \mathrm{SD},(\mathrm{n}=6$, duplicate). *Indicates significant difference from control $(P<0.05)$.

\begin{tabular}{ccccc}
\hline & $\mathrm{mg} / \mathrm{L}$ & $\mathrm{ALT}$ & $\mathrm{AST}$ & Glucose \\
\cline { 2 - 5 } Rhamdia & 0.0 & $142 \pm 3.46$ & $43.4 \pm 2.91$ & $45.5 \pm 4.17$ \\
quelen & 0.2 & $148 \pm 6.85^{*}$ & $49.7 \pm 4.71^{*}$ & $39.9 \pm 2.60^{*}$ \\
& 0.4 & $155 \pm 5.80^{*}$ & $66.8 \pm 7.50^{*}$ & $37.3 \pm 1.88^{*}$ \\
& & & & \\
Leporinus & 0.0 & $374 \pm 32.04$ & $16.6 \pm 3.11$ & $65.0 \pm 2.70$ \\
obtusidens & 0.2 & $654 \pm 73.19^{*}$ & $27.2 \pm 2.47^{*}$ & $63.1 \pm 1.44$ \\
& 0.4 & $712 \pm 75.10^{*}$ & $28.0 \pm 3.05^{*}$ & $50.3 \pm 2.71^{*}$ \\
\hline
\end{tabular}

In addition, the effects of glyphosate were also evaluated through the protein and glucose levels in the mucus layer. The glucose and protein levels exhibited a significant increase in the mucus layer of both silver catfish and piava that were exposed to both concentrations of the glyphosate herbicide, when compared to control group (Table 2).

Table 2. Protein and glucose levels of the mucus layer of Rhamdia quelen and Leporinus obtusidens after glyphosate exposure $(96 \mathrm{~h})$. Protein was expressed $\mu \mathrm{g}$ protein $/ \mathrm{cm}^{2}$. Glucose was expressed $\mu \mathrm{g}$ sugar $/ \mathrm{cm}^{2}$. Data are reported as mean $\pm \mathrm{SD}$ ( $\mathrm{n}=6$, duplicate). "Indicates significant difference from control $(\mathrm{P} \leq 0.05)$.

\begin{tabular}{cccc}
\hline & $\mathrm{mg} / \mathrm{L}$ & Protein & Glucose \\
\cline { 2 - 4 } Rhamdia & 0.0 & $0.016 \pm 0.002$ & $0.013 \pm 0.001$ \\
quelen & 0.2 & $0.019 \pm 0.001^{*}$ & $0.018 \pm 0.001^{*}$ \\
& 0.4 & $0.031 \pm 0.003^{*}$ & $0.020 \pm 0.001^{*}$ \\
& & & \\
Leporinus & 0.0 & $0.011 \pm 0.001$ & $0.010 \pm 0.001$ \\
obtusidens & 0.2 & $0.018 \pm 0.004^{*}$ & $0.019 \pm 0.001^{*}$ \\
& 0.4 & $0.021 \pm 0.001^{*}$ & $0.021 \pm 0.003^{*}$ \\
\hline
\end{tabular}

Furthermore, the effects of glyphosate on NPTase and ecto-5'-nucleotidase activity were observed in the brain of silver catfish and piava. Glyphosate promoted a significant increase in ATP and ADP hydrolysis at 0.2 and $0.4 \mathrm{mg} / \mathrm{L}$ in silver catfish, when compared to the control group (Fig. 1A). In terms of the ecto-5'-nucleotidase activity, the results showed that the herbicide, at both concentrations, also promoted an increase in AMP hydrolysis in silver catfish, when compared to control group (Fig. 1A). On the other hand, in piava exposure to glyphosate caused a significantly decrease in ATP, ADP, and AMP hydrolysis at 0.2 and 0.4 $\mathrm{mg} / \mathrm{L}$ when, compared to control group (Fig. 1B).

In addition, silver catfish and piava that were exposed to the herbicide showed an increase in protein carbonyl content in the liver at both concentrations when compared to control group (Fig. 2).

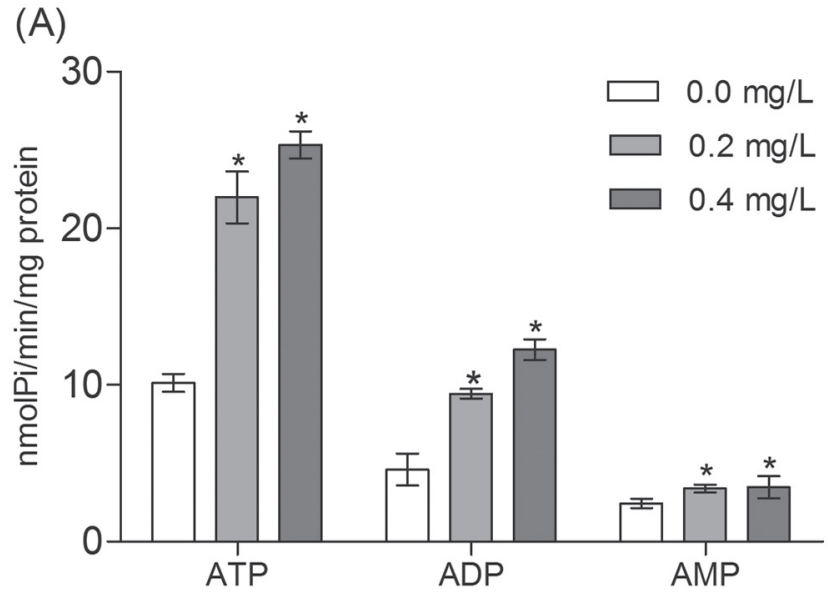

(B)

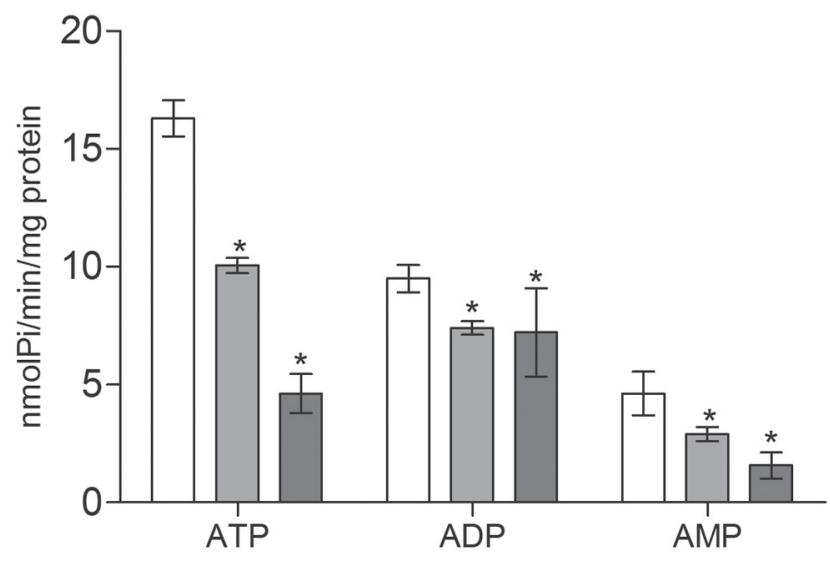

Fig. 1. NTPDase and ecto-5'-nucleotidase activities in the brain of Rhamdia quelen (A) and Leporinus obtusidens (B) that were exposed to glyphosate for 96 h. Data represent the mean \pm SD $(n=6$, in duplicate). *Indicates difference significant compared to the control group $(\mathrm{P} \leq 0.05)$.

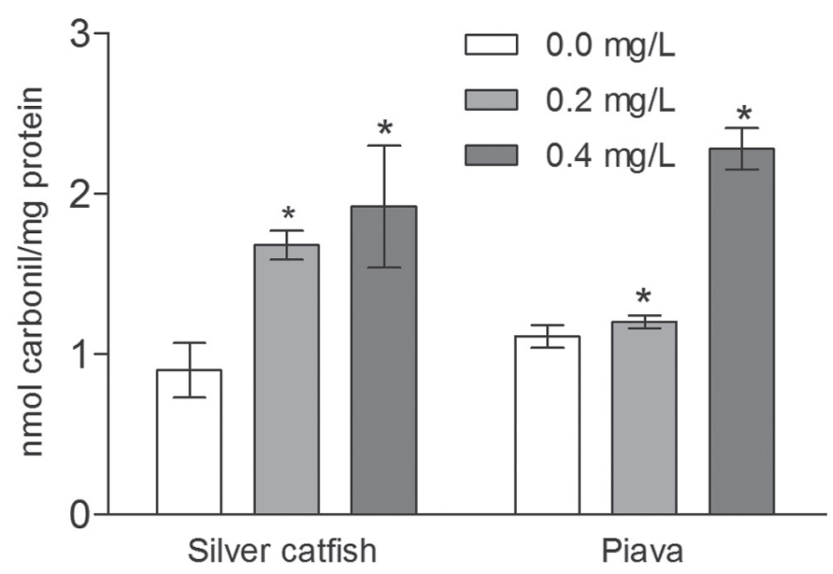

Fig. 2. Protein carbonyl levels in the liver of Rhamdia quelen and Leporinus obtusidens that were exposed to glyphosate for $96 \mathrm{~h}$. Data represent the mean $\pm \mathrm{SD}(\mathrm{n}=6$, in duplicate). ${ }^{*}$ Indicates difference significant compared to control group $(\mathrm{P} \leq 0.05)$. 


\section{Discussion}

Blood parameters might be a useful tool for understanding the impact of pesticides in several fish species, owing to the sensibility and indication of physiopathological alterations under different conditions of stress (Modesto \& Martinez, 2010; Kreutz et al., 2011). The decreased plasmatic glucose levels can cause hypoglycemia. Thus, our results indicate that the hypoglycemia observed was probably a consequence of the rapid utilization of blood glucose during hyperexcitability, which is a characteristic response of both fish species to herbicide poisoning. Alterations in blood glucose levels have also been reported in Leporinus obtusidens that were exposed to the herbicide 2,4-D for $96 \mathrm{~h}$ (Fonseca et al., 2008).

Among the different types of enzyme, both AST and ALT were proven to play an essential role in the metabolism of proteins and carbohydrates. In this context, they appear to be reliable in demonstrating liver damage caused by pesticides (Gholami-Seyedkolaei et al., 2013). In the present study, the plasma transaminases results showed liver damage under glyphosate exposure. Considering that the concentration of the active ingredient that is available to the fish in the present study is very low, it is possible to consider that environmental concentrations found in water near agricultural areas could be toxic to the liver of fish species. The liver damage was evidenced through some laboratory studies by Crestani et al. (2006) who observed increased transaminase when $R$. quelen were exposure to clomazone $(0.5$ or $1.0 \mathrm{mg} / \mathrm{L})$. Other authors have demonstrated increased AST and ALT activity when Cyprinus carpio were exposed to glyphosate at 3.5, 7, and $14 \mathrm{mg} / \mathrm{L}$ (Gholami-Seyedkolaei et al., 2013). An increase in these enzymatic activities (ALT and AST) in the extracellular fluid or plasma may be a sensible indicator of cellular liver damage caused by glyphosate exposure.

Another important parameter evaluated in this study was the mucus layer, which represents an external protection layer for fish, The results presented herein demonstrate that glyphosate exposure increased the glucose and protein levels in the mucus layers of both fish species studied. Glusczak et al. (2011) also observed an increase in glucose and protein levels in the mucus layer of $L$. obtusidens that were exposed to $3,6,10$, or $20 \mathrm{mg} / \mathrm{L}$ glyphosate for $96 \mathrm{~h}$. The alterations in carbohydrate and protein contents in the mucus layer of silver catfish and piava could be indicative of form of protection against external agents and microbial development. The epidermal mucus in fish is considered a key component of innate immunity, which is primarily produced by epidermal goblet cells or mucus cells and is composed of water and gel-forming macromolecules including mucins and other glycoproteins, which formulate a defense system against aquatic microorganisms and parasites (Benhamed et al., 2014).
ATP and adenosine are known to produce potent effects when released from neurons and astrocytes (Wink et al., 2003). Extracellular adenine nucleotides and nucleosides have been related with several physiological and pathological conditions in the central nervous system (CNS). The increase in enzymes involved in ATP hydrolysis in silver catfish may be attributed to an extremely toxic situation, with increased adenine nucleotide hydrolysis and, consequently, increased adenosine content. In addition, inhibitory effects were observed for ATP, ADP, and AMP in piava, which leads us to propose that different NTPDases are involved in the control of nucleotide hydrolysis in the CNS of this species. This reduction may indicate tissue hypoxia caused by herbicide toxicity. Senger et al. (2005) reported that carbofuran $(50$ and $500 \mu \mathrm{g} / \mathrm{L}$, 7 days exposure) significantly decreased ADP hydrolysis in the brain of Danio rerio, whereas $500 \mu \mathrm{g} / \mathrm{L}$ malation did not significantly alter ATP and AMP hydrolysis. The same authors considered the hypothesis that pesticides are indirectly modulate ectonucletidase activities, probably by affecting the transduction signal pathways (Senger et al., 2004; 2005).

Thus, the different responses to glyphosate exposure from the two species may be attributed to differences in the structure, habitat, reproduction and nutrition of each species. Furthermore, NTPDase and ecto- 5'-nucleotidase activities in the brain may be considered modulators of CNS functions and may be fundamental tools in the assessment of CNS injury. Therefore, this enzymatic system is an important tool for the maintenance and control of concentrations of extracellular purines and consequently, for the regulation of the balance between purinergic excitatory and inhibitory activities (Cunha, 2001). Other processes may also explain the inhibitory effect observed in the ecto-nucleotidase activities. In this study, it was shown that glyphosate is able to induce liver protein oxidation. This phenomenon could partially explain the toxicity demonstrated by the ecto-enzyme activity. Thus, the possibility of glyphosatemediated oxidative damage to proteins in the brains of fish cannot be discarded.

After glyphosate exposure, the protein carbonyl content increased in the liver of both species, which is one of the key biochemical changes that occurs during protein oxidation. Similar results shown by Glusczak et al. (2011), as L. obtusidens that were exposed to 3, 6, 10, or $20 \mathrm{mg} / \mathrm{L}$ glyphosate for $96 \mathrm{~h}$ showed an increase in protein carbonyl content in this tissue. Another study also observed an increase in protein carbonyl content after $48 \mathrm{~h}$ of exposure to deltamethrin, endosulfan or paraquat in Channa punctata (Parvez \& Raisuddin, 2005). In addition, this elevation results in the accumulation of damaged molecules, owing to an impairment of normal protein metabolism.

Thus, our investigation shows that although there are differences between the two fish species, they exhibit similar responses to the toxicity caused by glyphosate herbicide. 


\section{Acknowledgments}

We would like to thank the Universidade Federal de Santa Maria (UFSM) for the support and the facilities, to CAPES by financial support for the student L. G. and the CNPq by financial support and research fellowship to V. L. L.

\section{Literature Cited}

Antunes, M. I. P. P., R. S. Spurio, D. A. Godoi, C. E. S. Grumadas \& M. A. Rocha. 2008. Cloridrato de benzocaína na anestesia de carpas (Cyprinus carpio). Semina: Ciências Agrárias, 29: 151-156.

Aparicio, V. C., E. D. Gerónimo, D. Marino, J. Primost, P. Carriquiriborde \& J. L. Costa. 2013. Environmental fate of glyphosate and aminomethylphosphonic acid in surface waters and soil of agricultural basins. Chemosphere, 93: 1866-1873.

Baldissarelli, L. A., K. M. Capiotti, M. R. Bogo, G. Ghisleni \& C. D. Bonan. 2012. Arsenic alters behavioral parameters and brain ectonucleotidases activities in zebrafish (Danio rerio). Comparative Biochemistry and Physiology - C Toxicology and Pharmacology, 155: 566-572.

Barnes, J. M., P. A. Murphy, D. Kirkham \& J. M. Henley. 1993. Interaction of guanine nucleotides with [3H]kainate and $6-[3 \mathrm{H}]$ cyano-7-nitroquinoxaline-2,3-dione binding in goldfish brain. Journal of Neurochemistry, 61: 1685-1691.

Benhamed, S., F. A. Guardiola, M. Mars \& M. A. Esteban. 2014. Pathogen bacteria adhesion to skin mucus of fishes. Vetrinary Microbiology, 171: 1-12.

Chan, K. M., D. Delfert \& K. D. Junger. 1986. A direct colorimetric assay for $\mathrm{Ca}^{2+}$-stimulated ATPase activity. Analytical Biochemistry, 157: 375-380.

Corbera, M., M. Hidalgo, V. Salvado \& P. P. Wieczorek. 2005. Determination of glyphosate and aminomethylphosphonic acid in natural water using the capillary electrophoresis combined with enrichment step. Analytica Chimica Acta, 540: 3-7.

Coupe, R. H., S. J. Kalkhoff, P. D. Capel \& C. Gregoire. 2012. Fate and transport of glyphosate and aminomethylphosphonic acid in surface waters of agricultural basins. Pest Management Science, 68: 16-30.

Crestani, M., C. Menezes, L. Glusczak, D. Dos Santos Miron, R. Lazzari, M. F. Duarte \& V. P. Vieira. 2006. Effects of clomazone herbicide on hematological and some parameters of protein and carbohydrate metabolism of silver catfish Rhamdia quelen. Ecotoxicology and Environmental Safety, 65: 48-55.

Cunha, R. A. 2001. Adenosine as a neuromodulator and as a homeostatic regulator in the nervous system: Different roles, different sources and different receptors. Neurochemistry International, 38: 107-125.

Cunha, R. A., T. Almeida \& J.A. Ribeiro. 2000. Modification by arachidonic acid of extra cellular adenosine metabolism and neuromodulatory action in the rat hippocampus. The Journal of Biological Chemistry, 275: 37572-37581.

Fonseca, M. B., L. Glusczak, B. S. Moraes, C. C. Menezes, A. Pretto, M. A. Tierno \& V. L. Loro. 2008. The 2,4-D herbicide effects on acetylcholinesterase activity and metabolic parameters of piava freshwater fish (Leporinus obtusidens). Ecotoxicology and Environmental Safety, 69: 416-20.
DuBois, M., K. A. Gilles, J. K. Hamilton, P. A. Rebers \& F. Smith. 1956. Colorimetric Method for determination of sugars and related substances. Analytical Chemistry, 28: 350-356.

Gholami-Seyedkolaei, S. J., A. Mirvaghefi, H. Farahmand \& A. A. Kosari. 2013. Effect of a glyphosate-based herbicide in Cyprinus carpio: Assessment of acetylcholinesterase activity, hematological responses and serum biochemical parameters. Ecotoxicology Environmental and Safety, 98: 135-141.

Glusczak, L., V. L. Loro, A. Pretto, B. S. Moraes, A. Raabe, M. F. Duarte, M. B. da Fonseca, C. C. de Menezes \& D. M. Valladão. 2011. Acute exposure to glyphosate herbicide affects oxidative parameters in piava (Leporinus obtusidens). Archives of Environmental Contamination and Toxicology, 61: 624-30.

Glusczak, L., D. S. Miron, B. S. Moraes, R. R. Simões, M. R. Schetinger, V. M. Morsch \& V. L. Loro. 2007. Acute effects of glyphosate herbicide on metabolic and enzymatic parameters of silver catfish (Rhamdia quelen). Comparative Biochemistry and Physiology - C Toxicology and Pharmacology, 146: 519-524.

Jiraungkoorskul, W., E. S. Upatham \& M. Kruatrachue. 2002. Histopathological effects of Roundup ${ }^{\circledR}$, a glyphosate herbicide, on Nile tilapia (Oreochromis niloticus). Science Asia, 28: 121-127.

Kreutz, L. C., L. J. G. Barcellos, S. F. Valle, T. O. Silva, D. Anziliero, E. D. Santos, M. Pivato \& R. Zanatta. 2011. Altered hematological and immunological parameters in silver catfish (Rhamdia quelen) following short term exposure to sublethal concentration of glyphosate. Fish \& Shellfish Immunology, 30: 51-57.

Lowry, O. H., N. J. Rosebrough, A. L. Farr \& R. J. Randall. 1951. Protein measurement with the folin phenol reagent. The Journal of Biological Chemistry, 193: 265-275.

Menezes, C., M. B. Fonseca, J. Leitemperger, A. Pretto, B. S. Moraes, C. R. Murussi, B. Baldisserotto \& V. L. Loro. 2014. Commercial formulation containing 2,4-D affects biochemical parameters and morphological indices of silver catfish exposed for 90 days. Fish Physiology Biochemistry. DOI: $10.1007 / \mathrm{s} 10695-014-9985-9$.

Modesto, K. A. \& C. B. R. Martinez. 2010. Effects of Roundup Transorb on fish: Hematology, antioxidant defenses and acetylcholinesterase activity. Chemosphere, 81: 781-787.

van der Oost, R., J. Beyer \& N. P. E. Vermeulen. 2003. Fish bioaccumulation and biomarkers in environmental risk assessment: a review. Environmental Toxicology and Pharmacology, 13: 57-149.

Ortiz-Ordoñez, E., E. Uría-Galicia, R. A. Ruiz-Picos, A. G. S. Duran,Y. H. Trejo, J. E. Sedeño-Díaz \& E. López-López. 2011. Effect of Yerbimat herbicide on lipid peroxidation, catalase activity, and histological damage in gills and liver of the freshwater fish Goodea atripinnis. Archives of Environmental Contamination and Toxicology, 61: 443-52.

Parvez, S. \& S. Raisuddin. 2005. Protein carbonyls: novel biomarkers of exposure to oxidative stress-inducing pesticides in freshwater fish Channa punctata (Bloch). Environmental Toxicology and Pharmacology, 20: 112-117.

Piola, L., J. Fuchs, M. L. Oneto, S. Basack, E. Kesten \& N. Casabé. 2013. Comparative toxicity of two glyphosate-based formulations to Eisenia andrei under laboratory conditions. Chemosphere, 91: 545-551. 
Rico, E. P., D. B. Rosemberg, K. J. Seibt, K. M. Capiotti, R. S. Da Silva \& C. D. Bonan. 2011. Zebrafish neurotransmitter systems as potential pharmacological and toxicological targets. Neurotoxicology and Teratology, 33: 608-617.

Rodrigues, B. N. \& F. S. Almeida. 2005. Guide to herbicides, $5^{\text {th }}$ Edition, IAPAR, Londrina, pp. 592.

Salbego, J., A. Pretto, C. Gioda, C. Menezes, R. Lazzari, J. Radünz Neto, B. Baldisserotto \& V. Loro. 2010. Herbicide formulation with glyphosate affects growth, acetylcholinesterase activity, and metabolic and hematological parameters in piava (Leporinus obtusidens). Archives of Environmental Contamination Toxicology, 58,740-745.

Santos, M. A., M. Pacheco \& I. Ahmad. 2004. Anguilla anguilla L. antioxidants responses to in situ bleached kraft pulp mill effluent outlet exposure. Environmental International, 30, 301-308.

Schetinger, M. R. C., V. L. P. Vieira, V. M. Morsch \& D. Balz. 2001. ATP and ADP hydrolysis in fish, chicken and rat synaptosomes. Comparative Biochemistry and Physiology B Biochemistry and Molecular Biology, 128: 731-741.

Senger, M. R., E. P. Rico, M. de Bem Arizi, D. B. Rosemberg, R. D. Dias, M. R. Bogo \& C. D. Bonan. 2005. Carbofuran and malathion inhibit nucleotide hydrolysis in zebrafish (Danio rerio) brain membranes. Toxicology, 212: 107-115.

Senger, M. R., E. P. Rico, R. D. Dias, M. R. Bogo \& C. D. Bonan. 2004. Ecto-5'-nucleotidase activity in brain membranes of zebrafish (Danio rerio). Comparative Biochemistry and Physiology. Part B, Biochemistry \& Molecular Biology, 139: 203-207.

Sevgiler, Y., P. Piner, H. Durmaz \& N. Üner. 2007. Effects of $\mathrm{N}$-acetylcysteine on oxidative responses in the liver of fenthion exposed Cyprinus carpio. Pesticide Biochemistry and Physiology, 87: 248-254.
Subramanian, S., N. W. Roos \& S. L. MacKinnon. 2008. Comparison of antimicrobial activity in the epidermal mucus extracts of fish. Comparative Biochemistry and Physiology, 150: 85-92.

Toni, C., C. Menezes, B. Clasen, J. Leitemperger, A. Pretto, M. B. Adaime \& V. L. Loro. 2013. Oxidative stress in carp exposed to quinclorac herbicide under rice field condition. Ecotoxicology and Environmental Safety, 92: 27-31.

Üner, N., E. Oruç \& Y. Sevgiler. 2005. Oxidative stress-related and ATPase effects of etoxazole in different tissues of Oreochromis niloticus. Environmental Toxicology and Pharmacology, 20: 99-106.

Wink, M. R., A. S. K.Tamajusuku, E. Braganhol, E. A. Casali, M. L. M. Barreto-Chaves, J. J. F. Sarkis \& A. M. O. Battastini. 2003. Thyroid hormone upregulates ecto-5'-nucleotidase CD73 in C6 rat glioma cells. Molecular and Cellular Endocrinology, 205, 107-114.

Yan, L. J., M. G. Traber \& L. Packer. 1996. Spectrophotometric method for determination of carbonyls in oxidatively modofied apolipoprotein B of human low-density lipoproteins. Analytical Biochemistry, 228, 349-351.

Zimmermann, H. 2001. Ectonucleotidases: seem recent developments and a note on nomenclature. Drug Development Research, 52, 44-56.

Submitted June 5, 2014 Accepted November 13, 2014 by Bernardo Baldisserotto Published March 31, 2015 
